\title{
Ripening of ovine milk cheeses: effects of plant rennet, pasteurization, and addition of starter on lipolysis
}

\author{
Maria J. Sousa \& F. Xavier Malcata* \\ Escola Superior de Biotecnologia. Universidade Católica Portuguesa, Rua Dr António Bernardino de Almeida, 4200 Parto, Portugal
}

\begin{abstract}
The influences of type of rennet (from animal sources or from flowers of Cynara cardunculus), pasteurization (or not) of the milk, and addition (or not) of starter cultures prior to cheesemaking, on the release of major fatty acid residues of ovine milk cheese were evaluated throughout the ripening period. The long-chain saturated $\left(C_{16: 0}\right.$ and $\left.C_{18: 0}\right)$ and unsaturated $\left(C_{18: 1}, C_{18: 2}\right.$ and $\left.C_{18: 3}\right)$ free fatty acids (FFA) were the most abundant types at all stages of ripening. The overall concentrations of FFA released by 68 days of ripening were 6517 and $7802 \mathrm{mg} \mathrm{kg}^{-1}$ cheese for ovine milk cheeses manufactured from the same batch of raw milk and ripened under the same conditions without deliberate addition of a starter culture, using plant or animal rennet, respectively; therefore, such plant rennet appears to be a good substitute for animal rennet from a lipolytic point of view. The overall concentrations of FFA in fresh cheese were 3538,3002 and $3283 \mathrm{mg} \mathrm{kg}^{-1}$ cheese for raw milk without addition of a starter culture, pasteurized milk without addition of a starter culture, and pasteurized milk with addition of a starter culture, respectively; these values increased to 6517,8115 and $4847 \mathrm{mg} \mathrm{kg}^{-1}$ cheese by 68 days, of which 1791,3887 and $1649 \mathrm{mg} \mathrm{kg}^{-1}$ cheese were accounted for by short-chain FFA. (C) 1997 Elsevier Science Ltd. All rights reserved
\end{abstract}

\section{INTRODUCTION}

Although extensive lipolysis may be considered undesirable in most cheese varieties (Fox et al., 1995), free fatty acids (FFA) contribute positively to the flavour characteristics of several types of cheese when properly balanced by the products of proteolysis and other enzyme-catalysed reactions, and they are precursors of more complex aroma compounds. Evaluation of lipolysis is done via measurement of the concentration of FFA (Woo et al., 1984); considering the pH range of most cheeses and the stability of ester bonds in glycerides containing aliphatic fatty acid residues in said range, the action of lipases appears to be the only feasible route for liberation of fatty acids residues from glycerides (Bills et al., 1969). Lipases in cheese originate from milk, rennet and starter or non-starter microflora (Fox et al., 1995). Indigenous lipoprotein lipase (LPL)

*To whom correspondence should be addressed. probably causes significant lipolysis in raw milk cheese (Olivecrona \& Bengtsson-Olivecrona, 1992), and it may also contribute to lipolysis in pasteurized milk cheese since extensive inactivation does not occur unless heating to above $78^{\circ} \mathrm{C}$ for at least $10 \mathrm{~s}$ is done (Driessen, 1989). Several microorganisms that are a part of the native microflora of raw milk cheeses have been reported to possess lipolytic activity (Stead, 1986), and lipases produced by psychrotrophic bacteria can be very heatresistant even though the bacteria themselves are readily inactivated by heat (Fairbairn \& Law, 1986). Lipolysis in milk preferentially releases short-chain and mediumchain fatty acids probably because most lipases are sn-1,3 specific (Brockerhoff \& Jensen, 1974)_-in milk triglycerides short chain acids are esterified predominantly at the $s n-3$ position-or because longer-chain acids are more susceptible to rcincorporation into triglycerides by lipase-catalysed ester synthesis. Lipolysis is expected to occur faster if the substrate concentration is increased; Irvine et al. (1948) reported that cheese manufactured 
from pasteurized milk retains more fat than cheese manufactured from raw milk. On the other hand, ovine milk, while containing the same basic constituents of bovine milk, has considerably higher levels of protein and fat (although this is not the case in ovine cheese) (e.g. Sousa \& Malcata, 1996a,b,c), and such values are of great importance for cheesemaking. Ovine milk fat contains a substantial proportion of monounsaturated fatty acids, but the proportion of polyunsaturated fatty acids is low; the profile of fatty acid residues in ovine milk has been reported by Olmedo and CollHellin (1976), and Gatusso and Fazio (1980) have shown that those present at the highest concentration are palmitic and oleic acids and, to a lesser extent, caproic, caprylic, linoleic and linolenic acids. Furthermore, ovine milk is characterized by having approximately twice the content of short-chain fatty acids $\left(\mathrm{C}_{4: 0}\right.$ to $\mathrm{C}_{12: 0}$ ) as bovine milk (Anifantakis, 1986; Nágera $e t$ al., 1993), and an even higher level of capric acid (Parodi, 1971).

Serra, a Portuguese ovine cheese manufactured from raw milk using extracts of flowers of Cynara cardunculus, was studied over a ripening period of 35 days throughout the cheesemaking season, and lipolysis seemed to proceed slowly (Macedo \& Malcata, 1996); the most concentrated FFAs throughout ripening were, according to chain length and degrees of saturation, butyric (short-chain), capric (medium-chain), palmitic and stearic (saturated long-chain) and oleic (unsaturated long-chain) acids. The aim of this study was to detcrminc the influcnce of biochemical and microbiological parameters on the profile of major FFAs in ovine cheese throughout ripening. Such selected parameters were: the type of rennet used to coagulate the milk (plant rennet obtained from flowers of Cynara cardunculus compared with a commercial animal rennet); inactivation of native microflora (pasteurized versus raw milk); and addition of defined microflora (addition of a commercial starter culture versus absence thereof).

\section{MATERIALS AND METHODS}

\section{Cheesemaking}

Raw ovine milk from the Serra da Esterla region was collected from a selected sheep flock of Bordaleira breed on the morning of cheesemaking and transported to the pilot plant under refrigerated conditions. The raw milk was then divided into four portions: two were pasteurized at $72^{\circ} \mathrm{C}$ for $15 \mathrm{~s}$, the other two received no heat treatment. Four batches of cheeses were then manufactured on the same day following an adaptation of the traditional technology: one from raw milk with plant rennet extracts of Cynara cardunculus (using $0.16 \mathrm{~g}$ of stylets of dry flowers, ground for $1 \mathrm{~min}$ and soaked in tap water for $10 \mathrm{~min}$, with stirring, per litre of milk) (denoted A cheeses); one from raw milk and animal rennet (1:10000 Stabo ${ }^{\circledR}$; Chr. Hansen's Lab, Denmark) (denoted B cheeses); one from pasteurized milk using plant rennet (denoted $\mathrm{C}$ cheeses); and a final batch from pasteurized milk using plant rennet and a starter culture (Flora danica ${ }^{\circledR}$ DRI/vac; Chr. Hansen's Lab) at the recommended level (denoted $\mathrm{D}$ cheeses). In the cheesemaking process, the milk (prepared in each case as detailed above) was heated to $28^{\circ} \mathrm{C}$ and salted $\left(3\right.$ glitre $\left.^{-1}\right)$; coagulation time varied from about $50 \mathrm{~min}$ to about $20 \mathrm{~min}$ (for extracts of $C$. cardunculus and animal rennet, respectively). The coagulum was cut, stirred for $30 \mathrm{~min}$, allowed to set to promote whey draining, placed into cylindrical moulds, and lightly pressed by hand. Fourteen cheeses of each type (A, B, C and D) were manufactured according to this experimental layout, for a total of 56 experimental cheeses. The cheeses were salted (with dry salt) on both surfaces (at ratios of about $3 \mathrm{~g} \mathrm{~kg}^{-1}$ cheese), and $24 \mathrm{~h}$ later placed in a maturation room maintained at $6^{\circ} \mathrm{C}$ and $92 \%$ relative humidity. After 2 weeks the cheeses were washed with warm and slightly salted water. The cheeses $(500 \pm 100 \mathrm{~g}$ in weight, $10 \pm 1 \mathrm{~cm}$ in diameter, $5 \pm 1 \mathrm{~cm}$ in height) were inverted daily for 68 days.

\section{Cheese sampling}

Two cheeses were taken at random from each batch at $0,7,14,28,42,56$ and 68 days of ripening. Five grams of each cheese were mixed, using a vortex, in a screwcapped test tube with $2.5 \mathrm{~g}$ of anhydrous sodium sulphate (Merck, Darmstadt, Germany) and $10 \mathrm{ml}$ of diethyl ether (Merck). Variable amounts (depending on the ripening time) of internal standard solution were then added; this mixture was stirred in the vortex for $1 \mathrm{~min}$ every $1 \mathrm{~h}$ for a period of $4 \mathrm{~h}$, and homogenized in a Sonorex RK100 (Bandelin, Berlin, Germany) for $15 \mathrm{~min}$ every $1 \mathrm{~h}$.

\section{Free fatty acid analyses}

The FFAs in the experimental samples were analysed by HPLC using the procedure initially developed by Garcia et al. (1990) and modified by Balcão and Malcata (1997). Each experimental datum was taken as the average of the aforementioned two replicates.

\section{RESULTS AND DISCUSSION}

The concentrations of free nonanoic $\left(\mathrm{C}_{9: 0}\right)$ and heptadecanoic $\left(\mathrm{C}_{17: 0}\right)$ acids in ovine milk cheeses have been reported to be rather low (Fuente et al., 1993), and often they have not been found at all (Gómez et al., 1987; Nágera et al., 1993). Preliminary analyses (not shown) confirmed that these acids were present in ovine milk cheeses at trace levels, and furthermore indicated that the ratio of $C_{9: 0}$ to $C_{17: 0}$ did not change significantly 
during ripening. Therefore, the use of these compounds as internal standards is appropriate.

Changes of individual FFAs during ripening are plotted in Fig. 1 for raw milk cheeses manufactured with plant rennet or animal rennet. The highest concentrations of FFA in fresh cheeses were for $\mathrm{C}_{18: 0}(999$ and $823 \mathrm{mg} \mathrm{kg}^{-1}$ cheese for $\mathrm{A}$ and $\mathrm{B}$ cheeses, respectively), $C_{16: 0}$ (695 and $580 \mathrm{mg} \mathrm{kg}^{-1}$ cheese), $\mathrm{C}_{18: 3}$ (445 and $529 \mathrm{mg} \mathrm{kg}^{-1}$ cheese) and $\mathrm{C}_{18: 1}$ (465 and $217 \mathrm{mg} \mathrm{kg}^{-1}$ cheese), whereas intermediate concentrations of $\mathrm{C}_{18: 2}$ (219 and $175 \mathrm{mg} \mathrm{kg}^{-1}$ cheese), $\mathrm{C}_{10: 0}$ (194 and $195 \mathrm{mg} \mathrm{kg}^{-1}$ cheese), $\mathrm{C}_{8: 0}$ (171 and $149 \mathrm{mg} \mathrm{kg}^{-1}$ cheese) and $\mathrm{C}_{4: 0}$ (157 and $156 \mathrm{mg} \mathrm{kg}^{-1}$ cheese) were found, and low concentrations of $\mathrm{C}_{12: 0}\left(111\right.$ and $108 \mathrm{mg} \mathrm{kg}^{-1}$ cheese) and $\mathrm{C}_{6: 0}$ (79 and $81 \mathrm{mg} \mathrm{kg}^{-1}$ cheese) were recorded; $C_{14: 0}$ found to be present in $B$ cheese $\left(193 \mathrm{mg} \mathrm{kg}^{-1}\right.$ cheese), but not in A cheese at 0 days of ripening, which is in agreement with results reported by Macedo and Malcata (1996) for Serra cheese (manufactured from raw ovine milk using plant rennet). As expected, the concentrations of all individual FFAs increased as ripening progressed; $C_{16: 0}, C_{18: 0}, C_{18: 2}$ and $C_{18: 3}$ were the most abundant FFAs at all stages of ripening for raw milk cheeses manufactured with either rennet, although long-chain fatty acids do not contribute to cheese flavour nearly as much as short-chain fatty acids (Baldwin et al., 1973). By 68 days of ripening, the major FFAs were $C_{4: 0}\left(450\right.$ and $463 \mathrm{mg} \mathrm{kg}^{-1}$ cheese for $A$ and B cheeses, respectively), $\mathrm{C}_{10: 0}\left(472\right.$ and $653 \mathrm{mg} \mathrm{kg}^{-1}$ cheese), $\mathrm{C}_{16: 0}$ (1204 and $1470 \mathrm{mg} \mathrm{kg}^{-1}$ cheese), $\mathrm{C}_{18: 0}$ (1320 and $1251 \mathrm{mg} \mathrm{kg}^{-1}$ cheese) and $\mathrm{C}_{18: 1}$ (1052 and $1599 \mathrm{mg} \mathrm{kg}^{-1}$ cheese). These results are in agreement with the FFA profile of Serra cheese (Macedo \& Malcata, 1996), Spanish ovine milk cheeses (Olmedo \& Coll-Hellin, 1976) and Italian ovine milk cheeses (Gatusso \& Fazio, 1980). The overall FFA concentrations in fresh cheese were 3538 and $3033 \mathrm{mg} \mathrm{kg}^{-1}$ cheese for cheeses A and B, respectively, which increased to 6517 and $7802 \mathrm{mg} \mathrm{kg}^{-1}$ cheese, respectively, by 68 days.

Changes in the concentrations of individual FFAs during ripening are plotted in Fig. 2 for raw milk cheeses (A), pasteurized milk cheeses (C), and pasteurized milk
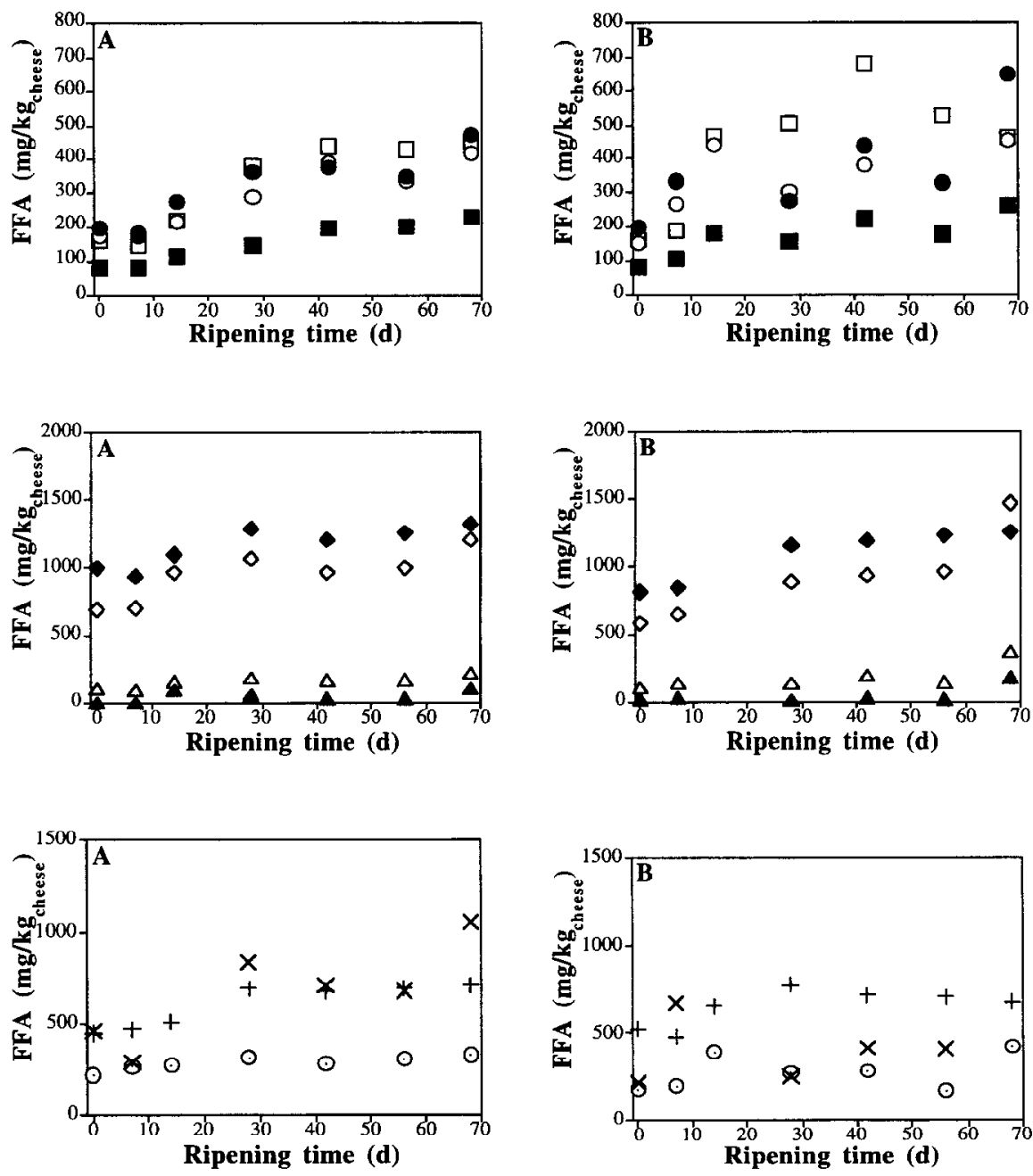

Fig. 1. Changes in concentration of individual free fatty acids throughout ripening, for raw milk cheeses nıanufactured using plant rennet $(A)$, or animal rennet $(B): C_{4: 0}(\square), C_{6: 0}(\square), C_{8: 0}(O), C_{10: 0}(\Theta), C_{12: 0}(\triangle), C_{14: 0}(\Delta), C_{16: 0}(\diamond), C_{18: 0}(\diamond), C_{18: 1}(\times), C_{18: 2}$ $(\odot)$ and $\mathrm{C}_{18: 3}(+)$. 
cheeses with addition of starter (D). The overall concentrations of FFAs in fresh cheese were 3538, 3002, and $3283 \mathrm{mg} \mathrm{kg}^{-1}$ cheese for cheeses A, C and D. In fresh cheese, the profiles of FFAs for $A, C$ and D cheeses were similar; the FFA present in high concentrations were $C_{18: 0}\left(999,784\right.$ and $811 \mathrm{mg} \mathrm{kg}^{-1}$ cheese for $A, C$ and $D$ cheeses, respectively), $C_{16: 0}(695,550$ and $\quad 612 \mathrm{mg} \mathrm{kg}^{-1}$ cheese), $\mathrm{C}_{18: 3} \quad(445, \quad 710$ and $808 \mathrm{mg} \mathrm{kg}^{-1}$ cheese) and $\mathrm{C}_{18: 2}\left(219,174\right.$ and $212 \mathrm{mg} \mathrm{kg}^{-1}$ cheese). Conversely, $\mathrm{C}_{18: 1}$ was present at higher concentrations in A cheese $\left(465 \mathrm{mg} \mathrm{kg}^{-1}\right.$ cheese) than in $\mathrm{C}$ or $D$ cheeses (139 and $207 \mathrm{mg} \mathrm{kg}^{-1}$ cheese, respectively). During ripening, $\mathrm{C}_{4: 0}, \mathrm{C}_{6: 0}, \mathrm{C}_{10: 0}, \mathrm{C}_{14: 0}$ and $\mathrm{C}_{18: 1}$ were the FFA that showed the highest fractional increase in cheeses $\mathrm{A}$ and $\mathrm{C}$; however, the fractional increase was higher in $C$ cheese $(9.55,5.62,5.96,8.12$ and 5.30, respectively) than in A cheese (2.85, 2.90, 2.43, 6.89 and 2.26 , respectively) by 68 days. The FFA that showed the highest fractional increase in $\mathrm{D}$ cheeses were $\mathrm{C}_{4: 0}$, $\mathrm{C}_{14: 0}$ and $\mathrm{C}_{18: 1}\left(5.61,4.40\right.$ and $5.30 \mathrm{mg} \mathrm{kg}^{-1}$ cheese, respectively), but the FFA values by 68 days were considerably lower than those in $\mathrm{A}$ or $\mathrm{C}$ cheeses. These results agree with the fact that lipases (either from milk, rennet or of microorganisms) involved in cheese ripening are selective for short- and medium-chain fatty acid residues (Fuente et al., 1993). In other varieties of cheese (namely, Majorero and Roncal), $\mathrm{C}_{4: 0}, \mathrm{C}_{14: 0}, \mathrm{C}_{16: 0}$ and $\mathrm{C}_{18: 1}$ have been reported to be the most abundant FFA, whereas in Idiazabal, $\mathrm{C}_{4: 0}$ and $\mathrm{C}_{14: 0}$ have been reported to be present at highest concentrations (Gómez et al., 1987; Fuente et al., 1993). The short-chain FFAs $\left(\mathrm{C}_{4: 0^{-}}\right.$ $\mathrm{C}_{12: 0}$ ) accounted for 1791,3887 and $1649 \mathrm{mg} \mathrm{kg}^{-1}$ cheese in A, C and D cheeses, respectively, of the overall values of 6517,8115 and $4847 \mathrm{mg} \mathrm{kg}^{-1}$ cheese measured by 68 days of ripening. The profile of short-chain FFA has been claimed to provide dairy products with unique organoleptic properties, and thus their fractional amount of the overall FFA can be regarded as a useful index in characterizing cheeses throughout the ripening period. (a)
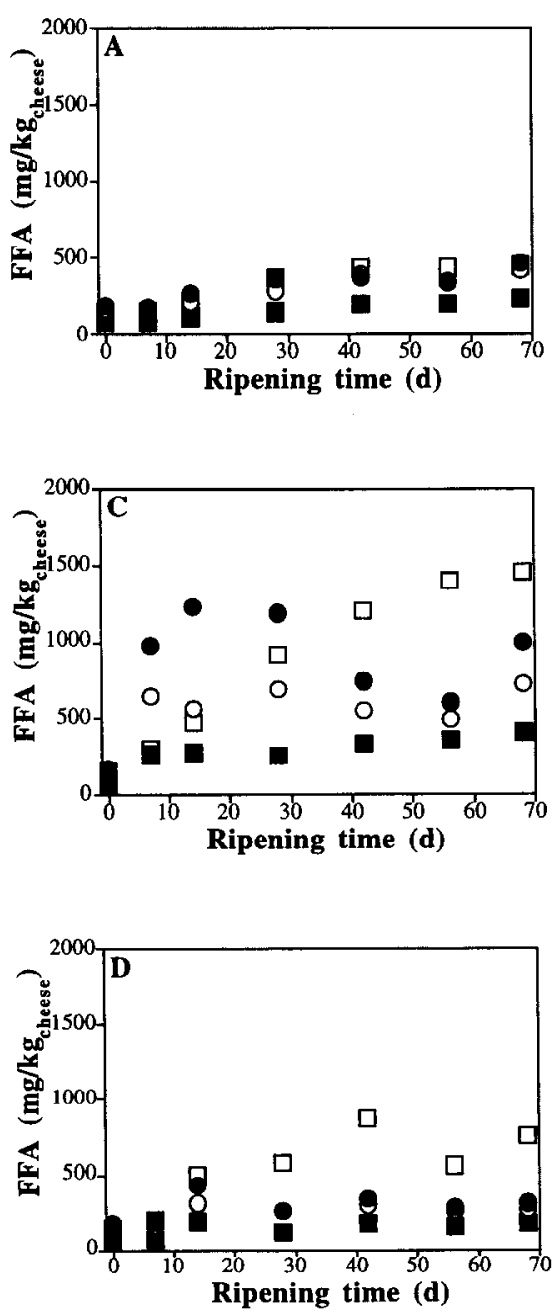

(b)
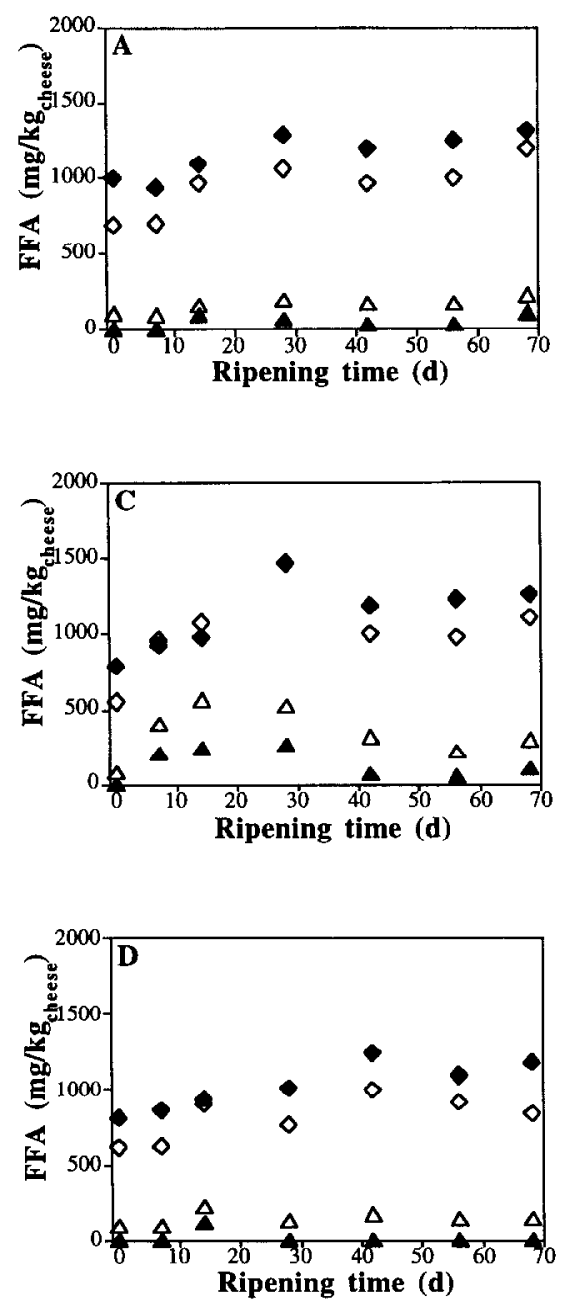

(c)
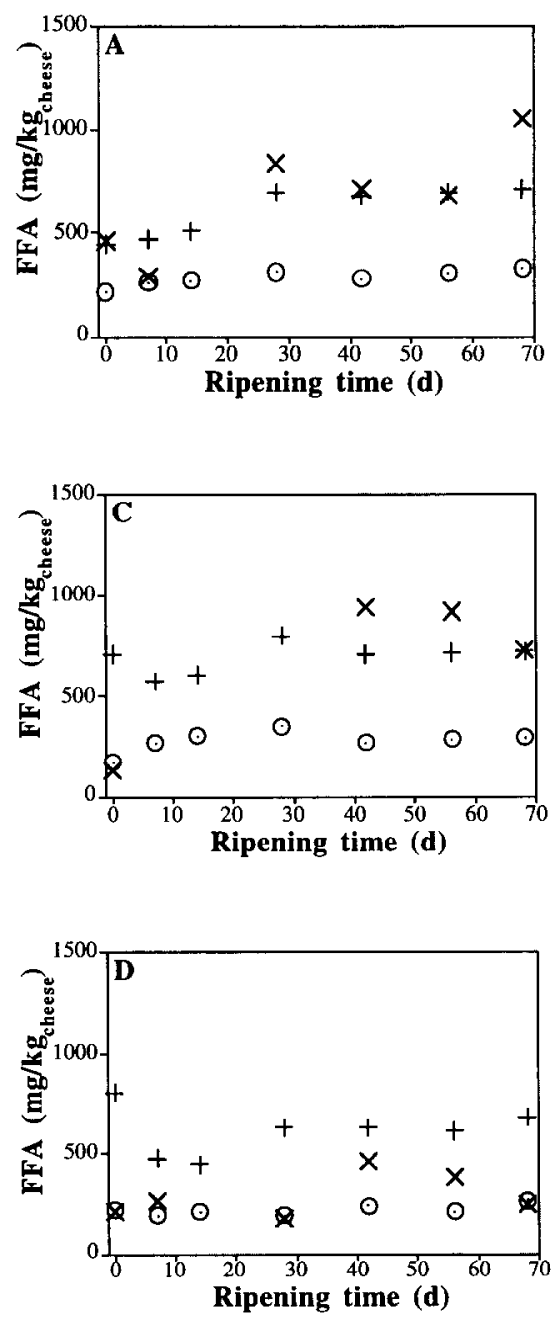

Fig. 2. Changes in concentration of individual free fatty acids throughout ripening, for raw milk cheeses (A), pasteurized milk cheeses (C), or pasteurized milk cheeses with starter addition (D), all manufactured using plant rennet: $C_{4: 0}(\square), C_{6: 0}(\square), C_{8: 0}(O)$, $\mathrm{C}_{10: 0}(\odot), \mathrm{C}_{12: 0}(\triangle), \mathrm{C}_{14: 0}(\Delta), \mathrm{C}_{16: 0}(\diamond), \mathrm{C}_{18: 0}(\diamond), \mathrm{C}_{18: 1}(\times), \mathrm{C}_{18: 2}(\odot)$, and $\mathrm{C}_{18: 3}(+)$. 
The overall FFA concentrations in fresh cheeses were 3538,3002 and $3283 \mathrm{mg} \mathrm{kg}^{-1}$ cheese for A, C and D cheeses, respectively, and 6517,8115 and $4847 \mathrm{mg} \mathrm{kg}^{-1}$ cheese by 68 days of ripening; therefore, the overall FFA concentration increased by 2979, 5112 and $1563 \mathrm{mg} \mathrm{kg}^{-1}$ cheese for A, C and D cheeses, respectively. The greater increase of the concentration of FFA in $C$ than in A cheeses was due to the fact that (1) cheese manufactured from pasteurized milk retains more fat $(90.2 \%)$ than cheese manufactured from raw milk $\left(88.7 \%\right.$ ) (Irvine et al., 1948), (2) pasteurization at $73^{\circ} \mathrm{C}$ for $15 \mathrm{~s}$ performed at the pilot facilities may not have inactivated all of the indigenous lipase in milk (Driessen, 1989), and (3) bacterial lipases in cheese are often rather heat-resistant (Fairbairn \& Law, 1986). Furthermore, pumping of the milk from the bulk tank to the pasteurizer and then to the cheese vat may disrupt the fat structure and make it more uniform in terms of globule size, thus increasing the specific surface area and consequently the rate of lipolysis (which is an interfacial reaction), or pumping of the milk may promote considerable foaming due to topical air leaks, which in turn activate native milk lipase (Reiter et al., 1969). The smaller increase in FFA in D cheese than in A or C cheeses may be a consequence of preferential growth of non-lipolytic microorganisms due to the microecological impact of the starter culture used, or a consequence of inactivation of lipase caused by the decrease in $\mathrm{pH}$ caused by growth of microorganisms; according to Reiter et al. (1969), cheese manufactured from raw milk contained appreciably higher concentrations of FFA than did cheese manufactured from heat-processed milk using a starter culture, and it is known that commercial starters are composed mainly of poorly lipolytic lactic acid bacteria.

Despite the differences between the experimental cheeses, lipolysis can, in general, be concluded to be low in $\mathrm{A}, \mathrm{B}, \mathrm{C}$ and $\mathrm{D}$ cheeses, probably because their ripening time was too short to allow extensive breakdown of milk fat. Similar results were obtained for Serra cheese (Macedo \& Malcala, 1996) and Serena cheese (Fernández del Pozo et al., 1988), both manufactured from ovine milk using a plant coagulant. Cheese varieties in which lipolysis is extensive are supplemented with lipases originating in the coagulant (such as rennet paste in Italian cheeses) or produced by deliberate addition of mould-adjunct starters which are extremely lipolytic (such as in mould-ripened cheeses) (Bills et al., 1969; Fernández-Salguero et al., 1986).

\section{ACKNOWLEDGEMENTS}

Financial support for M. J. Sousa was granted by program PRAXIS XXI (BD-2763/93) through a PhD fellowship. Partial funding for this research work was provided by program AAIR (EC) through project 'Design and production of an enzymatic and microbial mixture to improve the process ewe's cheese (Spain, France, Italy and Portugal) safety and quality and to get a novel functional food as a response to European demand for new products low in cholesterol and protein enriched', and by Agência de Inovação (Portugal) through project 'MAQUETTE: MelhorAmento de QUEijos Tradicionais e sua TEcnologia'. The authors are deeply indebted to the members of Estação Experimental de Lacticínios (Direç̧ão Regional de Agricultura de Entre Douro e Minho, Paços de Ferreira, Portugal) for their cooperation in the experimental manufacture and ripening of cheeses. The technical help of Victor Balcão in the implementation of the analytical procedure of assaying for free fatty acids is also gratefully acknowledged.

\section{REFERENCES}

Anifantakis, E. M. (1986). Comparison of the physicochemical properties of ewe's and cow's milk. Bull. Int. Dairy Fed., 202, 42-53.

Balcão, V. M. \& Malcata, F. X. (1997). Lipase-catalysed modification of butterfat via acidolysis with oleic acid. $J$. Mol. Catal. B, accepted.

Baldwin, R. E., Cloninger, M. R. \& Lindsay, R. C. (1973). Flavour thresholds for fatty acids in buffered solutions. $J$. Food Sci., 38, 528-530.

Bills, D. D., Scanlan, R. A., Lindsay, R. C. \& Sather, L. (1969). Free fatty acids and the flavour of dairy products. $J$. Dairy Sci., 52, 1340-1345.

Brockerhoff, H. \& Jensen, R. G. (1974). Milk lipases. In Lipolytic Enzymes. eds H. Brackenhoff \& R. G. Jensen. Academic Press, London, pp. 118-129.

Driessen, F. W. (1989). Heat-induced changes in milk. Bull. Int. Dairy Fed., 238, 24-30.

Fairbairn, D. J. \& Law, B. A. (1986). Proteinases of psychrotrophic bacteria: their production, properties, effects and control. J. Dairy Res., 53, 139-177.

Fernández del Pozo, B., Gaya, B., Medina, M., RodríguezMarin, M. \& Nuñez, M. (1988). Changes in chemical and rheological characteristics of La Serena ewe's milk cheese during ripening. $J$. Dairy Res., 55, 457-464.

Fernández-Salguero, J., Florido, S., Alcalá, M., Marcos, A. \& Esteban, M. A. (1986). Fatty acids composition in some Spanish mold-ripened cheeses. Grasas Aceites, 3, $152-155$.

Fox, P. F., Singh, T. K. \& McSweeney, P. L. H. (1995). Biogenesis of flavour compounds in cheese. In Chemistry of Structure-Function Relationships in Cheese, eds E. L. Malin \& M. M. Tunick. Plenum Press, London, pp. 59-98.

Fuente, M. A., Fontecha, J. \& Juárez, M. (1993). Fatty acid composition of the tryglyceride and free fatty acid fractions in different cows-, ewes- and goats-milk cheeses. $Z$. Lebersm. Unters. Forsch., 38, 155-158.

Garcia, H., Reyes, H. R., Malcata, F. X., Hill, C. H. \& Amundson, C. H. (1990). Determination of the major free fatty acids in milkfat using a three-component mobile phase for HPLC analysis. Milchwissenschaft, 45, 757-759.

Gatusso, A. M. \& Fazio, G. (1980). Characteristics and composition of milk fat from sheep of Sicilian breeds. Riv. Ital. Sostanze Grasse, 57, 530-535.

Gómez, R., Fernández-Salgnero, J. \& Marcos, A. (1987). Composicion en acidos grasos libres y combinados de quesas comerciales. Grasas y Aceiles., 38, 23-26. 
Irvine, O. R., Bryant, L. R., Hill, D. C. \& Sproule, W. H. (1948). A comparison of the yields of Cheddar cheese. Can. Dairy Ice Cream J., 27, 49-52.

Macedo, A. C. \& Malcata, F. X. (1996). Changes in the major free falty acids in Serra cheese throughout ripening. Int. Dairy J., 6, 1087-1097.

Nágera, A. I., Barrón, L. J. R. \& Barcina, Y. (1993). Review: Lipidic fraction composition of cow's, sheep's, and goat's cheese, and the influence on its quality. Rev. Esp. Cienc. Tecnol. Aliment., 33, 345-363.

Parodi, P. W. (1971). Detection of synthetic and adulterated butter fat. 3. Triglyceride and fatty acid analysis. Aust. I. Dairy Technol., 26, 155-158.

Olivecrona, T. \& Bengtsson-Olivecrona, G. (1992). Indigenous enzymes in milk lipase. In Advanced Dairy Chemistry, Vol. 1, Proteins, ed. P. F. Fox. Elsevier Applied Science, London, pp. 292-310.

Olmedo, G. R. \& Coll-Hellin, L. (1976). Contribution al estudio de la grasa de leche de ovejas españolas. Anal. Bromatol., 38, 211-340.
Reiter, B., Sorokin, Y., Pickering, A. \& Hall, A. J. (1969). Hydrolysis of fat and protein in small cheeses made under aseptic conditions. J. Dairy Sci., 36, 65-76.

Sousa, M. J. \& Malcata, F. X. (1996). Influence of pasteurization of milk and addition of starter cultures on protein breakdown in ovine cheeses manufactured with extracts from flowers of Cynara cardunculus. Food Chem., 57, 549-556.

Sousa, M. J. \& Malcata, F. X. (1997a). Comparison of plant and animal rennets on microbiological, chemical and biochemical characteristics of ovine cheese. J. Agric. Food Chem., 45, 74-81.

Sousa, M. J. \& Malcata, F. X. (1997h). Comparative biochemical evolution during ripening of bovine, ovine and caprine cheeses manufactured with extracts of flowers of Cynara cardunculus. Z. Lebensm. Unters. Forsch., in press.

Stead, D. (1986). Microbial lipases: their characteristics, role in food spoilage and industrial uses. $J$. Dairy Res., 53, 481-505.

Woo, A. H., Kollodge, S. \& Lindsay, R. C. (1984). Quantification of major free fatty acids in several cheese varieties. $J$. Dairy Sci., 67, 874-878. 